\title{
Fastlegen og heroinmisbrukeren
}

\author{
Norsk narkotikapolitikk følger et blindspor, trass i alle gode hensikter. Selv med enorme \\ investeringer dør unødig mange, og rehabiliteringen lider. Fastlegene kan og bør spille \\ hovedrollen i behandling og rehabilitering av de heroinavhengige.
}

Våre fagmiljøer ivrer etter å innføre nye effektive metoder, men ikke i behandlingen av våre ca. 10000 tungt heroinavhengige (1). Her har Norge tatt skylappene på, med ambivalens til de livreddende medisinene buprenorfin og metadon. Et sett av betingelser skal oppfylles før legemiddelassistert rehabilitering (LAR) tilbys: vanligvis medikamentfritt behandlingsforsøk (med stor fare for overdose etter utskrivning), kommunal tilrettelegging og en velvillig fastlege. Ca. 5000 er med i LAR, 60 \% får metadon, resten buprenorfin (2). I narkotikadebatten etterlyses det institusjonsplasser for over $4000 \mathrm{i}$ kø, en kø som heller burde henvises til våre 4000 fastleger for snarlig forskrivning av buprenorfin.

Dagfinn Haarr har vist at behandling av rusmiddelavhengighet $\mathrm{i}$ allmennpraksis resulterte i en lavere dødelighet $(0,5 \%)$, enn ved $\operatorname{LAR}(1,3 \%)$, og utenfor $\operatorname{LAR}(5,1 \%)$ (3). Medisinering stabiliserer og muliggjør rehabilitering. Spesielt motiverte greier helt å kutte ut medisinene, helst ved innleggelse $\mathrm{i}$ institusjon.

\section{Langt høyere}

\section{overdosedødsfall enn i EU}

Jeg vil tallfeste våre dårlige resultater, som ikke skyldes manglende satsing. Tvert imot har vi verdens dyreste metode. Helseforetakene alene brukte i 20083 milliarder kroner til rusbehandling (Samdata). Jeg har, fra de sist tilgjengelige EU-tallene (4), beregnet overdosedødeligheten i Norge, Frankrike (5) og EU ut fra nøyaktige befolkningstall i perioden 1985-2006. Beregningene mine oppgir jeg som eksakte tall, for å få et så godt utgangspunkt for diskusjon og handling som mulig.

I 1989 lå Norge og EU likt med ti slike dødsfall per million innbyggere (EU 9,80, Norge 10,66). Etter 1990 har Norge hele tiden ligget høyere (fig 1). Fra 1990 til 1997 var gjennomsnittlig dødelighet i Norge 1,9 ganger så høy som i EU, henholdsvis 28,9 og 15,0 per million innbyggere. LAR ble innført i 1998. De tilsvarende tallene deretter, til 2006, viser økning til henholdsvis 61,4 per million innbyggere (dvs. 278 døde i Norge) og 15,9 per million innbyggere (dvs. estimert 72 døde i tilsvarende EUbefolkning). Gjennomsnittlig alder ved død er i EU og Norge ca. 35 år (6).

\section{Lær av Frankrike!}

I 1995 startet substitusjonsoffensiven i Frankrike, første året med metadon, deretter fortrinnsvis med buprenorfin (Subutex) (fig 1). Straks gikk overdosedødsfallene bratt ned i tre år, fra 9,5 til et nivå på 3,6 per million innbyggere $-4,8$ per million innbyggere etter ny beregningsmåte i 2005 og 2006 (fig 1). De franske politibaserte tallene var inntil da gjennomgående for lave. Fordi de har vært registrert på samme måte i mange år, egner de seg allikevel til å anslå trenden.

Behandlingen i Frankrike er godt tilrettelagt ved gratis konsultasjoner og medisin. Legene, som ikke får noen spesiell opplæring, forskriver for en ukes forbruk av gangen, og ny resept utleveres hver 4 . uke (7). Kontroll av urin og inntak av buprenorfin (som brukes av $80 \%$, metadon av $20 \%$ ) foretas sjelden. Lekkasje av buprenorfin til gaten kan faktisk bidra positivt.

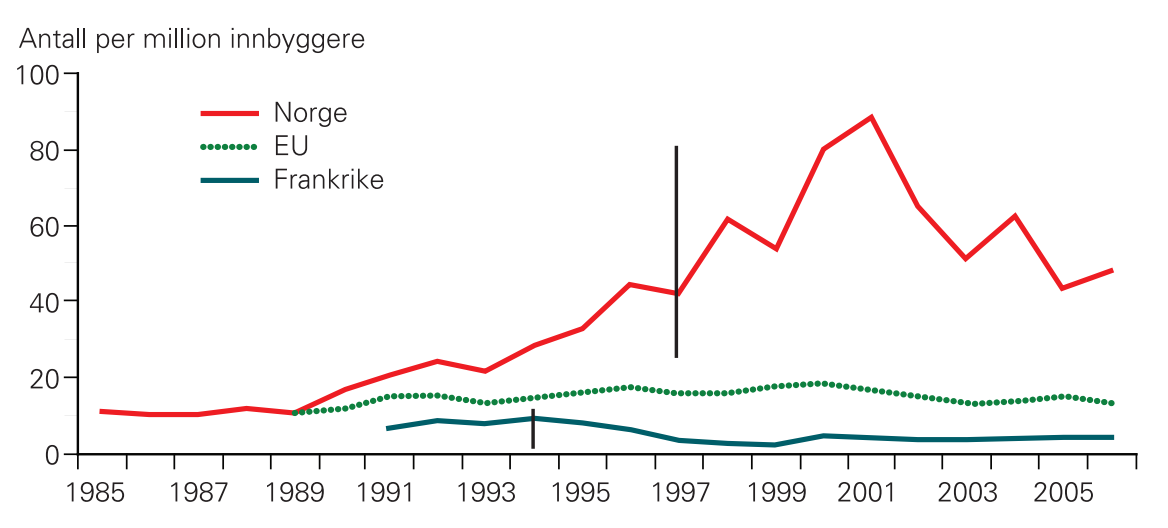

Figur 1 Overdosedødsfall per million innbyggere i Norge, EU og Frankrike 1985 til 2006 (4). Verti-

kale linjer markerer året før fransk substitusjonsoffensiv i 1995 og norsk LAR-oppstart i 1998
Dette lite giftige opioidet er populært for å erstatte heroin, men er lite egnet som rusmiddel for ikke-narkomane. Nettoeffekten er at det totale herointrykket reduseres (8), med færre dødsfall og færre nyrekrutterte på heroin. Å kunne tone ned kontrollene gir en stor gevinst for alle parter i behandlingen og rehabiliteringen. Den nødvendige oppfølgingen fra fastlegenes side bør stimuleres med økning av behandlingstakstene akkurat for denne pasientgruppen. LAR må få en tilbaketrukket støttefunksjon, akkurat som andre spesialistinstanser har. Med det franske systemet som utgangspunkt kan vi hjelpe alle narkomane i Norge som ber om hjelp.

\section{Martin Haraldsen \\ mar.har@c2i.net \\ Rødslia 12 \\ 3222 Sandefjord}

Oppgitte interessekonflikter: Ingen

\section{Litteratur}

1. Bretteville-Jensen AL, Amundsen EJ. Heroinforbruk og heroinbeslag i Norge. Sirusrapport nr. 8/2009. Oslo: Statens institutt for rusmiddelforskning, 2009: 36

2. Waal $H$, Clausen $T$, Håseth A et al. LAR i Norge 10 år. Seraf-rapport 2008. Oslo: Senter for rusog avhengighetsforskning, 2008.

3. Haarr D, Nessa J. Opioidbehandling av rusmiddelavhengige i en allmennpraksis. Tidsskr Nor Lægeforen 2007; 127: 1770-2

4. Number of drug-induced deaths recorded in EU Member States according to national definitions. European Monitoring Centre for drugs and drug addiction. Statistical bulletin 2009 (www.emcdda. europa.eu/stats09/drdtab107a) (12.11.2009).

5. Eurostat http://epp.eurostat.ec.europa.eu/portal/ page/portal/eurostat/home/ (15.12.2009)

6. EMCDDA annual report 2008: the state of the drug problem in Europe. Lisboa, European Drug Monitoring Centre for Drugs and Drug Addiction, 2008: 84.

7. Fatseas M, Auriacombe M. Why buprenorphine is so successful in treating opiate addiction in France. Curr Psychiatry Rep 2007; 9: 358-64.

8. Alho H, Sinclair D, Vuori E et al. Abuse liability of buprenorphine-naloxone tablets in untreated IV drug users. Drug Alcohol Depend 2007; 88: 75-8.

Manuskriptet ble mottatt 19.5. 2009 og godkjent 19.11. 2009. Medisinsk redaktør Anne Kveim Lie. 